\section{The food environment of Brazilian public and private schools}

\author{
O ambiente alimentar das escolas públicas e \\ privadas no Brasil
}

\section{El ambiente alimentario de las escuelas públicas y privadas en Brasil}

\author{
Ariene Silva do Carmo 1 \\ Maíra Macário de Assis 1 \\ Cristiane de Freitas Cunha 1 \\ Tatiana Resende Prado Rangel de Oliveira 2 \\ Larissa Loures Mendes 1
}

doi: 10.1590/0102-311X00014918

\begin{abstract}
This study's aim was to characterize the food environment of Brazilian public and private schools. This was a national school-based cross-sectional study with 1,247 schools - among which $81.09 \%$ were public and $18.91 \%$ were private - in 124 Brazilian municipalities. The data originated from the Questionnaire on Aspects of the School Environment, used in the Study of Cardiovascular Risk in Adolescents (ERICA) in 2013 and 2014. Data analysis was conducted in 2017. The chi-square test was used to compare proportions. A greater proportion of public schools offered school meals (98.15\%) in comparison to private schools $(8.07 \%)(p<0.001)$. The internal sale of food and beverages was more prevalent in private schools $(97.75 \%$ vs. $45.06 \%, p<$ 0.001). Also, sale and advertisement of processed and ultra-processed foods (sodas, cookies, savory snacks, sandwiches and pizza), as well as the presence of vending machines for industrialized products $(18.02 \%$ vs. $4 \%)(p<0.001)$ were more common in private schools. Street vendors at the school gate or surroundings were identified in $41.32 \%$ of the public schools and $47.75 \%$ of the private schools $(p>0.05)$. These findings reveal the predominance of obesogenic environments mainly in private schools, and can contribute to the design of Brazilian public policies to promote a healthy school food environment.
\end{abstract}

Feeding; Adolescent; Schools

\section{Correspondence}

A. S. Carmo

Escola de Enfermagem, Universidade Federal de Minas Gerais. Av. Prof. Alfredo Balena 190, Belo Horizonte, MG 30130-100, Brasil.

arienecarmo@gmail.com

1 Escola de Enfermagem, Universidade Federal de Minas Gerais, Belo Horizonte, Brasil.

2 Pontifícia Universidade Católica de Minas Gerais, Belo Horizonte, Brasil. 


\section{Introduction}

The increasing prevalence of chronic non-communicable diseases (NCD) such as hypertension, obesity, type 2 diabetes and cardiovascular diseases among adolescents has been associated with increased consumption of ultra-processed foods, combined with a sedentary lifestyle 1,2,3. This condition results from the complex interaction of multiple factors, at various levels and contexts, including the individual, family, school, environment, community and public policies 4 .

The school environment is an important place to learn and gain experience related to children and adolescents' food intake. In this environment, the purchase and consumption of food occurs through cafeterias or school surroundings 5 . Thus, the school is considered a crucial place for carrying out activities related to health promotion and adequate nutrition 6 .

Ultra-processed foods are ready-to-eat products subjected to various industrial processing and numerous ingredients such as preservatives and stabilizers, sugar, sodium and/or fat. Examples of ultra-processed foods are sugar-sweetened beverages, confectioneries, stuffed biscuits, industrialized snacks, among others 7 . The offer and publicity of these foods in schools can encourage the adoption of inappropriate eating habits 8 .

According to studies previously conducted in American and Brazilian schools, children and adolescents who have easy access to fast-food cafeterias or food outlets (selling processed foods within walking distance of their schools) are more exposed to obesogenic eating environments 5,9.

According to Swinburn et al. 10, "obesogenic environments" are spaces that favor weight gain by stimulating the excessive consumption of unhealthy foods, or that lack infrastructure for leisure and physical activity. Such environments can induce the development of obesity, especially in individuals who have a genetic predisposition 11. In this regard, school environments can be either obesogenic or leptogenic, depending on what is offered by their cafeterias and surroundings.

Considering the epidemic of obesity and the growing consumption of ultra-processed foods, the increasing sedentary lifestyle of children and adolescents, and the role played in these phenomena by schools' food environments, this study's goal was to characterize the food environment of Brazilian public and private schools.

\section{Methods}

This research analyzed data from the national Study on Cardiovascular Risks in Adolescents (ERICA). The ethical procedures and criteria for data processing employed here were the same as the national study's. ERICA is a national, school-based, cross-sectional study aimed at estimating the prevalence of diabetes mellitus, obesity, cardiovascular risk factors, inflammatory markers, and insulin resistance in adolescents aged 12 to 17, enrolled in public and private schools in Brazilian cities with more than 100,000 inhabitants 12. The study was approved by the Research Ethics Committees of its central coordinating institution (Institute of Public Health Studies/Federal University of Rio de Janeiro), and also by each Brazilian state.

Data collection occurred between March 2013 and December 2014. We evaluated 74,589 adolescents from 1,247 schools in 124 Brazilian municipalities. The population of the research was divided into 32 strata consisting of 27 capitals and five sets of municipalities with more than 100,000 inhabitants, in each of the country's five geographic macro-regions. For each geographic stratum, the schools were selected with probability proportional to size and inversely proportional to distance from the capital. The sample is representative of medium and large-sized municipalities ( $>100,000$ inhabitants) at the national and regional levels, and of the Brazilian capitals. The ERICA research protocol was described by Bloch et al. 13 .

Three separate questionnaires were used for data collection: one for students, one for parents or guardians, and another for the school personnel. The school questionnaire contained specific questions directed to the school board, in addition to questions about the school environment, which were answered by the field researcher through inspection of the school area.

In this article, only the data from the Questionnaire on Aspects of the School Environment were used: school meal offered, presence of food and beverage vending machines, presence of processed food 
advertisements, presence of a well-structured cafeteria (a specific place, surrounded by walls and containing chairs and tables) inside the school premises, and presence of street vendors selling food and beverages in the school's surroundings. It should be noted that "surroundings" refer to the school's sidewalks. The sale of food and beverages - specifically some ultra-processed foods (sodas, biscuits, confectioneries, savory snacks, sandwiches, and pizza) - was evaluated according to the classification proposed by Monteiro et al. 7 .

Data analysis was conducted in 2017, using Stata software version 13.0 (https://www.stata.com). Descriptive analysis involved calculating the relative frequency distribution and its corresponding $95 \%$ confidence interval $(95 \% \mathrm{CI})$, and comparing proportions using the chi-square test. A significance level of $5 \%$ was adopted $(\mathrm{p}<0.05)$.

\section{Results}

A total of 1,247 Brazilian schools were evaluated, among which 19\% were in the North region, 30.4\% in the Northeast, $23.4 \%$ in the Southeast, $12.9 \%$ in the South and $14.3 \%$ in the Central. Among the evaluated schools, $81.1 \%$ were public and $18.9 \%$ were private.

A higher proportion of public schools offered school meals (98.1\%) compared to private schools $(8 \%)(\mathrm{p}<0.001)$. The presence of street vendors at the school gate or surroundings was identified in $58.6 \%$ of the public schools and $47.7 \%$ of the private schools. Approximately $60 \%$ of the public and private schools had well-structured cafeterias with no statistically significant differences between them ( $\mathrm{p}>0.05)$ (Table 1$)$.

In private schools, the sale of food and beverages in general $(97.75 \%$ vs. $45.06 \%, p<0.001)$ was more prevalent as well as the presence of food and beverage vending machines $(14.4 \% \%$ vs. $5.5 \%, \mathrm{p}<0.001)$ in school premises. Also, the sale and advertisement of ultra-processed foods (sodas, biscuits, confectioneries, savory snacks, sandwiches and pizza) was more frequent (18\% vs. $4.7 \%, \mathrm{p}<0.001)$ (Table 1$)$.

When the public schools were evaluated according to Brazilian regions, there was no prevalence difference in the offering of school meals regarding the type of region ( $p>0.05)$, while for other food environment characteristics, there was a difference among the regions $(\mathrm{p}<0.05)$. Vending machines for food and beverages were more frequent in the North region compared to the Northeast and South regions. The Northeast and South regions had the lowest prevalence of ultra-processed food advertisements in schools. The Northeast Region presented the lowest proportion of sale of food in schools in comparison to the other regions. Regarding the presence of a well-structured school cafeteria, the Southeast region had a higher proportion in comparison to all others, except for the South. Regarding the presence of street vendors at the school gate or surroundings, the North presented a higher proportion compared to the Southeast, South and Central regions (Table 2).

Regarding the evaluation of private schools according to region, there were no differences among the regions with respect to the provision of school meals, the presence of street vendors, the advertisement of ultra-processed foods and the sale of the majority of evaluated foods $(\mathrm{p}>0.05)$. The highest proportion of vending machines was found in the Northeast region in comparison to the South and Central regions. The sale of confectioneries was more frequent in the North and Northeast regions in comparison to the South and Southeast regions. Regarding the sale of sodas, the South region had the lowest proportion in comparison to all other regions, while the Northeast presented a higher proportion than the Southeast region. Well-structured cafeterias were more frequent in the South region compared to the Central region (Table 3).

\section{Discussion}

These findings show that private Brazilian schools have a more obesogenic food environment than public schools, with a greater predominance of sales and advertisements of processed foods and beverages. The food environment of the public and private schools in the Northern region of the country was more obesogenic, while the private and public schools in the South as well as the public schools in the North had fewer obesogenic environments. 
Table 1

Characterization of food environment in Brazilian public and private schools. Study of Cardiovascular Risk in Adolescents (ERICA), 2013-2014 ( $=1,247)$.

\begin{tabular}{|c|c|c|c|c|c|}
\hline \multirow[t]{2}{*}{ Variables } & \multicolumn{2}{|c|}{ Public } & \multicolumn{2}{|c|}{ Private } & \multirow[t]{2}{*}{ p-value * } \\
\hline & $\%$ & $95 \% \mathrm{Cl}$ & $\%$ & $95 \% \mathrm{Cl}$ & \\
\hline Offers school meal & 98.1 & $97.2-98.9$ & 8.0 & $4.4-11.6$ & $<0.001$ \\
\hline Has beverage and food vending machine & 5.5 & $4.1-6.9$ & 14.4 & $9.7-19.0$ & $<0.001$ \\
\hline Sale of food in school & 45.0 & $41.9-48.1$ & 97.7 & $95.7-99.7$ & $<0.001$ \\
\hline Sale of confectioneries in school & 35.7 & $32.6-38.7$ & 79.7 & $73.2-84.1$ & $<0.001$ \\
\hline Sale of sweet biscuits and savory snacks in school & 32.7 & $29.7-35.7$ & 76.1 & $70.4-81.7$ & $<0.001$ \\
\hline Sale of soda in school & 34.9 & $31.9-37.9$ & 75.2 & $69.5-80.9$ & $<0.001$ \\
\hline Sale of fried or baked savory snacks & 40.6 & $37.5-43.7$ & 93.2 & $89.9-96.5$ & $<0.001$ \\
\hline Sale of sandwiches in school & 25.5 & $22.8-28.3$ & 85.1 & $80.4-89.8$ & $<0.001$ \\
\hline Sale of pizza in school & 15.2 & $13.0-17.5$ & 73.7 & $67.9-79.6$ & $<0.001$ \\
\hline Presence of processed food advertisement & 4.7 & $3.3-6.0$ & 18.9 & $13.7-24.1$ & $<0.001$ \\
\hline Presence of a well-structured cafeteria & 59.6 & $56.5-62.7$ & 54.0 & $47.4-60.6$ & 0.125 \\
\hline Presence of street vendors at school gate or surroundings & 58.6 & $55.5-61.7$ & 47.7 & $45.6-58.8$ & 0.081 \\
\hline
\end{tabular}

95\% Cl: 95\% confidence interval.

* Chi-square test.

Table 2

Characterization of food environment in public schools, according to Brazilian region. Study of Cardiovascular Risk in Adolescents (ERICA), $2013-2014$ $(n=1,012)$.

\begin{tabular}{|c|c|c|c|c|c|c|c|c|c|c|c|}
\hline \multirow[t]{2}{*}{ Variables } & \multicolumn{2}{|c|}{ North } & \multicolumn{2}{|c|}{ Northeast } & \multicolumn{2}{|c|}{ Southeast } & \multicolumn{2}{|c|}{ South } & \multicolumn{2}{|c|}{ Central } & \multirow[t]{2}{*}{ p-value * } \\
\hline & $\%$ & $95 \% \mathrm{Cl}$ & $\%$ & $95 \% \mathrm{Cl}$ & $\%$ & $95 \% \mathrm{Cl}$ & $\%$ & $95 \% \mathrm{Cl}$ & $\%$ & $95 \% \mathrm{Cl}$ & \\
\hline Offers school meal & 98.4 & $96.7-100.0$ & 96.7 & $94.6-98.8$ & 98.2 & $96.5-99.9$ & 100.0 & - & 98.5 & $96.6-100.0$ & 0.234 \\
\hline $\begin{array}{l}\text { Has beverage and food } \\
\text { vending machine }\end{array}$ & 11.1 & $6.6-15.5$ & 2.5 & $0.6-4.3$ & 6.0 & $2.9-9.2$ & 1.6 & $0.6-3.8$ & 6.3 & $2.2-10.3$ & $<0.001$ \\
\hline Sale of food in school & 59.0 & $52.1-65.9$ & 26.2 & $21.0-31.4$ & 44.3 & $37.8-50.8$ & 51.6 & $42.6-60.5$ & 57.7 & $49.5-65.9$ & $<0.001$ \\
\hline $\begin{array}{l}\text { Sale of confectioneries in } \\
\text { school }\end{array}$ & 51.0 & $43.9-58.0$ & 23.7 & $18.7-28.7$ & 36.5 & $30.2-42.7$ & 25.0 & $17.2-32.7$ & 45.7 & $37.8-54.0$ & $<0.001$ \\
\hline $\begin{array}{l}\text { Sale of sweet biscuits and } \\
\text { savory snacks in school }\end{array}$ & 48.2 & $41.1-55.2$ & 20.5 & $15.7-25.2$ & 33.0 & $26.9-39.1$ & 33.0 & $24.6-41.4$ & 34.5 & $26.5-42.4$ & $<0.001$ \\
\hline Sale of soda in school & 50.5 & $43.4-57.5$ & 23.0 & $18.0-28.0$ & 35.2 & $28.9-41.4$ & 25.0 & $17.2-32.7$ & 45.0 & $36.7-53.3$ & $<0.001$ \\
\hline $\begin{array}{l}\text { Sale of fried or baked } \\
\text { savory snacks in school }\end{array}$ & 54.5 & $47.5-61.5$ & 23.7 & $18.7-28.7$ & 38.8 & $32.5-45.2$ & 47.5 & $38.6-56.4$ & 51.4 & $43.0-59.7$ & $<0.001$ \\
\hline $\begin{array}{l}\text { Sale of sandwiches in } \\
\text { school }\end{array}$ & 29.0 & $22.6-35.4$ & 16.5 & $12.1-20.9$ & 31.0 & $24.9-37.0$ & 33.8 & $25.4-42.3$ & 22.5 & $15.5-29.4$ & $<0.001$ \\
\hline Sale of pizza in school & 20.4 & $14.7-26.1$ & 11.8 & $8.0-15.6$ & 6.5 & 3.3-9.7 & 33.0 & $24.6-41.4$ & 13.3 & $7.7-19.0$ & $<0.001$ \\
\hline $\begin{array}{l}\text { Presence of processed } \\
\text { food advertisement in } \\
\text { school }\end{array}$ & 8.0 & $4.2-11.9$ & 3.9 & $1.6-6.2$ & 0.8 & $0.0-2.0$ & 1.6 & $0.0-3.8$ & 10.5 & $5.4-15.6$ & $<0.001$ \\
\hline $\begin{array}{l}\text { Presence of a well- } \\
\text { structured cafeteria }\end{array}$ & 56.0 & 49.0-73.0 & 48.2 & $42.2-54.1$ & 83.4 & $78.6-88.3$ & 77.4 & $69.9-84.8$ & 33.1 & $25.2-40.9$ & $<0.001$ \\
\hline $\begin{array}{l}\text { Presence of street } \\
\text { vendors at the gate and } \\
\text { surroundings of the } \\
\text { school }\end{array}$ & 70.1 & $64.3-77.1$ & 64.3 & $58.7-70.0$ & 57.8 & $51.4-64.3$ & 36.5 & $27.9-45.2$ & 51.0 & $42.7-59.4$ & $<0.001$ \\
\hline
\end{tabular}

95\% Cl: 95\% confidence interval.

* Chi-square test. 
Table 3

Characterization of food environment in private schools, according to Brazilian region. Study of Cardiovascular Risk in Adolescents (ERICA), 2013-2014 $(n=236)$.

\begin{tabular}{|c|c|c|c|c|c|c|c|c|c|c|c|}
\hline \multirow[t]{2}{*}{ Variables } & \multicolumn{2}{|c|}{ North } & \multicolumn{2}{|c|}{ Northeast } & \multicolumn{2}{|c|}{ Southeast } & \multicolumn{2}{|c|}{ South } & \multicolumn{2}{|c|}{ Central } & \multirow[t]{2}{*}{ p-value * } \\
\hline & $\%$ & $95 \% \mathrm{Cl}$ & $\%$ & $95 \% \mathrm{Cl}$ & $\%$ & $95 \% \mathrm{Cl}$ & $\%$ & $95 \% \mathrm{Cl}$ & $\%$ & $95 \% \mathrm{Cl}$ & \\
\hline Offers school meal & 4.0 & $0.0-12.2$ & 5.8 & $0.7-10.8$ & 9.8 & $1.3-18.2$ & 23.0 & $5.7-40.4$ & 2.8 & $0.0-8.6$ & 0.032 \\
\hline $\begin{array}{l}\text { Has beverage and food } \\
\text { vending machine }\end{array}$ & 20.0 & $3.8-36.8$ & 23.5 & $14.3-32.7$ & 7.8 & $0.2-15.4$ & 3.8 & $0.0-11.76$ & 5.7 & $0.0-13.8$ & 0.013 \\
\hline Sale of food in school & 100.0 & - & 98.8 & $96.4-100.0$ & 94.1 & $87.4-100.0$ & 100.0 & - & 97.1 & 91.3-100.0 & 0.316 \\
\hline $\begin{array}{l}\text { Sale of confectioneries } \\
\text { in school }\end{array}$ & 88.0 & 74.3-100.0 & 90.4 & $84.0-96.8$ & 70.5 & $57.6-83.5$ & 50.0 & 29.4-70.5 & 77.1 & $62.5-91.7$ & $<0.001$ \\
\hline $\begin{array}{l}\text { Sale of sweet biscuits } \\
\text { and savory snacks in } \\
\text { school }\end{array}$ & 76.0 & $58.0-93.9$ & 83.5 & $75.4-91.5$ & 76.4 & $64.4-88.5$ & 73.0 & $54.8-91.3$ & 60.0 & $42.9-77.0$ & 0.103 \\
\hline Sale of soda in school & 92.0 & $80.5-100.0$ & 89.4 & $82.7-96.0$ & 68.6 & $55.4-81.8$ & 30.7 & $11.7-49.7$ & 71.4 & $55.6-87.1$ & $<0.001$ \\
\hline $\begin{array}{l}\text { Sale of fried or baked } \\
\text { savory snacks in school }\end{array}$ & 100.0 & - & 94.1 & $89.0-99.0$ & 92.1 & $84.5-99.7$ & 92.3 & $81.3-100.0$ & 88.5 & 77.4-99.6 & 0.515 \\
\hline $\begin{array}{l}\text { Sale of sandwiches in } \\
\text { school }\end{array}$ & 92.0 & $80.5-100.0$ & 87.0 & 79.7-94.3 & 90.2 & $81.7-98.6$ & 80.7 & $64.5-97.0$ & 71.4 & $55.6-87.1$ & 0.099 \\
\hline Sale of pizza in school & 80.0 & $63.1-96.8$ & 78.5 & $69.6-87.5$ & 70.6 & $57.6-83.5$ & 76.9 & $59.5-94.2$ & 60.0 & $42.9-77.0$ & 0.255 \\
\hline $\begin{array}{l}\text { Presence of processed } \\
\text { food advertisement in } \\
\text { school }\end{array}$ & 32.0 & $12.3-51.6$ & 23.5 & $14.3-32.7$ & 13.7 & $3.9-23.5$ & 0.0 & - & 20.0 & $0.6-33.9$ & 0.027 \\
\hline $\begin{array}{l}\text { Presence of a well- } \\
\text { structured cafeteria }\end{array}$ & 44.0 & $23.0-64.0$ & 60.0 & 49.3-70.6 & 50.9 & $36.7-65.1$ & 73.0 & $54.8-91.3$ & 37.1 & 20.3-53.9 & 0.037 \\
\hline $\begin{array}{l}\text { Presence of street } \\
\text { vendors at the gate and } \\
\text { surroundings of the } \\
\text { school }\end{array}$ & 56.0 & $35.0-76.9$ & 48.2 & $37.3-59.0$ & 56.8 & $42.7-70.9$ & 34.6 & $15.0-54.2$ & 65.7 & $49.1-82.2$ & 0.141 \\
\hline
\end{tabular}

95\% Cl: 95\% confidence interval.

* Chi-square test.

Almost all Brazilian public schools offer school meals, with no difference among the regions. This is due to the Brazilian National School Feeding Program (PNAE) 14, implemented in 1955 with the aim of contributing to the growth, development, learning, school performance of students, and the development of healthy eating habits, through the provision of school meals and nutritional education interventions. Currently, PNAE serves all basic education students (kindergarten, elementary school, high school and Youth and Adult education) enrolled in public, philanthropic schools and community entities (affiliated to public authority) through the transfer of financial resources.

According to the current PNAE legislation, priority is given to fresh and minimally processed foods. Thirty percent of all the resources destined to PNAE must be used in the purchase of products from family-based farms and the menu must offer three portions of fruits and vegetables per week (200g/student/week). On the other hand, ultra-processed products such as canned foods, sausages, beverages with low nutritional value and sweets are prohibited or restricted in the school menu 15.

Thus, the provision of school meals in public schools, coupled with lower sales and advertisement of processed foods in school premises, can generate a healthier food environment and lead to better food consumption among students. Some Brazilian studies have evidenced the benefits of school meals offered in Brazilian public schools for healthy eating practices. A study conducted in 2015, with a representative national sample of Brazilian adolescents, found lower consumption of sugar, sugar-sweetened beverages, processed and ultra-processed foods among students in public schools compared to private schools 16 . Another study conducted with 1,357 public school students from a 
capital city in the Southeast region of Brazil revealed that children who consumed 2 or 3 daily school meals had a $7.3 \%$ higher intake of fresh foods, and a $10.5 \%$ higher intake of minimally processed foods. They also had a $18 \%$ and $26 \%$ lower consumption of ultra-processed foods when compared to children who did not consume school meals 17.

With regard to the sale of processed foods and beverages in school premises, Interministerial Ordinance n. 1,010/2006 18 establishes guidelines for the Promotion of Healthy Eating in Brazilian public and private schools at the primary, middle and high school levels. It also supervises the restriction of sales and commercial promotion in school food environments, and limits the preparation of foods with high levels of saturated fats, trans fats, free sugars and salts, encouraging the consumption of fruits, legumes and vegetables. However, almost all private schools and approximately one-third of the public schools evaluated sell processed foods and beverages in school premises. It should be noted that, despite the ordinance's guidance, there is no mechanism put in place to monitor and supervise the commerce of processed foods and beverages.

Until March 2013 (when data collection for this study commenced), 10 of the 26 Brazilian states had some kind of legal provision (ordinance, resolution, decree or law) concerning the sale of food in the school environment: 1 in the North Region (7 states) ${ }^{19}$, none in the Northeast (9 states), 2 in the Central (3 states) 20,21, 4 in the Southeast (4 states) 22,23,24,25 and 3 in the South (3 states) 26,27,28. Among these, 4 applied only to public schools and the rest applied to both public and private schools, which explains the results of this study, showing a higher proportion of private schools selling ultraprocessed foods in the school environment in comparison to public schools.

Furthermore, according to a study conducted by the Brazilian Ministry of Health in order to identify and analyze experiences in the regulation of food sales in the school environment, the presence of the PNAE in public schools facilitates adherence to these regulations, since the students are given an alternative to the cafeteria. As reported by the study, it is noteworthy that, in the public school system, the system tends to comply with the regulation, as it is legitimized by a higher court. This differs greatly from the reality of private schools, where there is a greater resistance to law enforcement and a lack of understanding concerning the school environment being a public space for interaction and learning of health habits. Furthermore, some factors were observed that may hinder adherence to the regulation of cafeterias as well as their adequate inspection, such as the degree of complexity of the law, specifications that lack clarity and objectivity, or incoherence regarding permitted and prohibited foods 29 .

In 2015-2016, four additional state laws were established in order to restrict the commerce of processed foods and beverages in the school environment. One applied to the North 30, 2 to the Northeast 31,32 and 1 to the Federal District (Brazil's capital) 33,34. They all applied to public and private schools. It is worth pointing out that, while the legislation is certainly moving forward, a national law is still needed for clearer regulation aimed at restricting the trade and propaganda of all ultra-processed foods in the premises of public and private schools, besides greater supervision and enforcement of the law. Nutritional education and the offering of healthier meals in schools have also been suggested as important measures to facilitate healthier food choices 29 .

The restriction of the commerce and advertising of these foods in the school space is crucial, since the excessive consumption of ultra-processed products is directly associated with metabolic syndrome among adolescents 3 , and also with obesity at all ages 35 .

Regarding the sale of food and beverage at the gates and surroundings of schools, a high prevalence of this practice was observed. In recent years there have been major changes in the food environment around schools, facilitating the consumption of food outside the home and increasing access to cheap and highly caloric foods 36 . A study conducted in New Zealand showed that the food environment in the surroundings of schools, even with a small effect size, can influence adolescents' dietary quality 37. Another study, carried out in the United States, highlighted that food from street vendors near schools was a significant part of students' energy intake 38 . All the above points to the importance of public policies that regulate the commerce of food in the surroundings of schools. Currently, however, Brazilian legal provisions on this subject are still scarce. In 2015, the Brazilian capital implemented a decree to forbid the sale of foods that are markers of unhealthy diet in a 50-meter radius of schools 34

With regard to the presence of advertisements for ultra-processed foods in school premises, this practice was more frequent in private schools. Several studies have quantified children and adoles- 
cents' exposure to advertisements, finding that increased exposure to unhealthy food advertisements leads to increased intake of unhealthy food $39,40,41$. A study conducted in the United States showed that adolescents with high susceptibility to advertisements were more likely to consume at least one sugarsweetened beverage per day $(\mathrm{OR}=1.73 ; 95 \% \mathrm{CI}$ : 1.21-2.47). There was a direct association between attraction to advertised foods and purchasing the product $(\mathrm{p}<0.001)$ in children and adolescents from a private school in Brazil 40. Thus, policies aimed at restricting the presence of advertisements for ultra-processed foods in school environments are of the utmost importance for the promotion of healthy food choices among adolescents. In May 2010, member states of the World Health Organization (WHO) approved a Set of Recommendations on Marketing of Foods and Non-Alcoholic Beverages for Children, which had as one of its recommendations the restriction of exposure to advertising of unhealthy foods in the school environment 42.

Finally, it is worth emphasizing that obesogenic environments such as the ones found in this study, especially in the case of private schools, may lead to less-healthy eating choices and, consequently, the development of obesity. Ecological models suggest that childhood obesity is the result of a complex series of factors that operate at multiple levels, from the individual to the family and school contexts, also involving the influence of public policies, the community and the environment 4 . Similarly, Davison et al. ${ }^{43}$ propose that infant and juvenile nutritional status is determined by the interaction of variables at multiple levels, including risk factors and characteristics of the children, parenting styles and family, as well as community, demographic and social characteristics. In the latter, the authors include school feeding programs, accessibility to food establishments in the community, and school environment. In this sense, international agreements such as the Global Strategy for Healthy Eating, Physical Activity and Health, by the WHO 44,45, as well as national policies such as the Strategic Action Plan for Tackling Chronic Non-Communicable Diseases 46 and the Intersectoral Strategy for the Prevention and Control of Obesity 47 have made recommendations aimed at promoting a favorable environment for healthy food choices, with emphasis on institutionalized spaces such as schools.

The present study has as a limitation the non-adjustment of sample weight in its analysis, since the sampling was designed to represent the data on adolescents, not schools. Another limitation of the study lies in the fact that it did not approach the socioeconomic profile of the students and of the territories in which the public and private schools are located, considering that evidence suggests a relationship between the characteristics of the food environments, the population's socioeconomic conditions, and the territory's economic characteristics 48,49. However, the subject of this study is highly relevant, since the characterization of food intake at the national level can help in the design of federal public policies that facilitate healthier food choices.

\section{Conclusion}

The prevalence of the sale of ultra-processed foods and the presence of street vendors in the surroundings of the schools were high, and in general, private schools presented a more obesogenic food environment than public schools. Considering the schools by geographic region, the food environment was more obesogenic in the public and private schools of the North Region, and less obesogenic in the public and private schools of the South region as well as in the public schools of the Northeast Region.

Such findings may contribute to the design of more efficient public policies aimed at making the school environment a place for health promotion, providing adequate and healthy food to Brazilian children and adolescents. 


\section{Contributors}

A. S. Carmo and M. M. Assis were responsible for the analysis and interpretation of the data and writing of the manuscript. T. R. P. R. Oliveira contributed to the research and data collection, writing of the manuscript and critical review of content. C. F. Cunha and L. L. Mendes critically reviewed the manuscript.

\section{Acknowledgments}

Science \& Technology Department/Science, Technology and Strategic Inputs Secretariat/Brazilian Ministry of Health; and Brazilian Ministry of Science, Technology, Innovation and Communication.

\section{References}

1. Treuth MS, Griffin IJ. Adolescência. In: Shills ME, Shike M, Ross AC, Caballero B, Cousins RJ, organizadores. Nutrição moderna na saúde e na doença. 2a Ed. Barueri: Manole; 2009. p. 878-90.

2. Toral N, Conti MA, Slater B. A alimentação saudável na ótica dos adolescentes: percepções e barreiras à sua implementação e características esperadas em materiais educativos. Cad Saúde Pública 2009; 25:2386-94.

3. Tavares LF, Fonseca SC, Rosa MLG, Yokoo EM. Relationship between ultra-processed foods and metabolic syndrome in adolescents from a Brazilian Family Doctor Program. Public Health Nutr 2012; 15:82-7.

4. Kremers SP, de Bruijn GJ, Visscher TL, van Mechelen W, de Vries NK, Brug J. Environmental influences on energy balance-related behaviors: a dual-process view. Int J Behav Nutr Phys Act 2006; 3:9.

5. Austin SB, Melly SJ, Sanchez BN, Patel A, Buka S, Gortmaker SL. Clustering of fast-food restaurants around schools: a novel application of spatial statistics to the study of food environments. Am J Public Health 2005; 95:1575-81.

6. Ministério da Saúde; Organização Pan-Americana da Saúde. Escolas promotoras da saúde: experiência do Brasil. Brasília: Ministério da Saúde; 2006.

7. Monteiro CA, Cannon G, Levy RB, Moubarac JC, Jaime P, Martins AP, et al. NOVA. The star shines bright. World Nutrition 2016; 7:28-40.

8. Louzada MLC, Martins APB, Canella DS, Baraldi LG, Levy RB, Claro RM, et al. Alimentos ultraprocessados e perfil nutricional da dieta no Brasil. Rev Saúde Pública 2015; 49:38.

9. Leite FHM, Oliveira MA, Cremm EC, Abreu DSC, Maron LR, Martins PA. Oferta de alimentos processados no entorno de escolas públicas em área urbana. J Pediatr (Rio J.) 2012; 88:328-34

10. Swinburn B, Egger G, Raza F. Dissecting obesogenic environments: the development and application of a framework for identifying and prioritizing environmental interventions for obesity. Prev Med 1999; 29(6 Pt 1):563-70.

11. Tyrrell J, Wood AR, Ames RM, Yaghootkar H, Beaumont RN, Jones SE, et al. Gene-obesogenic environment interactions in the UK Biobank study. Int J Epidemiol 2017; 46:559-75.

12. Vasconcellos MTL, Silva PLN, Szklo M, Kuschnir MCC, Klein CH, Abreu GA, et al. Sampling design for the Study of Cardiovascular Risks in Adolescents (ERICA). Cad Saúde Pública 2015; 31:921-30.

13. Bloch KV, Szklo M, Kuschnir MCC, Abreu GA, Barufaldi LA, Klein CH, et al. The study of cardiovascular risk in adolescents - ERICA: rationale, design and sample characteristics of a national survey examining cardiovascular risk factor profile in Brazilian adolescents. BMC Public Health 2015; 15:94. 
14. Fundo Nacional de Desenvolvimento da Educação. Sobre o PNAE. http://www.fnde.gov. $\mathrm{br} /$ programas/alimentacao-escolar (accessed on Jul/2017).

15. Fundo Nacional de Desenvolvimento da Educação. Resolução no 26, de 17 de junho de 2013. Dispõe sobre o atendimento da alimentação escolar aos alunos da educação básica no âmbito do Programa Nacional de Alimentação Escolar - PNAE. Diário Oficial da União 2013; 18 jun.

16. Azeredo CM, de Rezende LF, Canella DS, Claro RM, Peres MF, Luiz OC, et al. Food environments in schools and in the immediate vicinity are associated with unhealthy food consumption among Brazilian adolescents. Prev Med 2016; 88:73-9.

17. Bento BMA, Moreira AC, Carmo AS, Santos LC, Horta PM. A higher number of school meals is associated with a less processed diet. J Pediatr (Rio J.) 2018; 94:404-9.

18. Ministério da Saúde. Portaria Interministerial no 1.010 , de 08 de maio de 2006. Institui as diretrizes para a Promoção da Alimentação Saudável nas Escolas de educação infantil, fundamental e nível médio das redes públicas e privadas, em âmbito nacional. Diário Oficial da União 2006; 9 mai.

19. Conselho Estadual de Alimentação Escolar. Resolução no 001/12/SECD/CEAE/RR, de 01 de agosto de 2012 (2012). Dispõe sobre os serviços de lanches nas Unidades Educacionais Públicas que atendam a Educação básica localizadas no Estado, que deverão obedecer a padrões de qualidade alimentar e nutricional, indispensáveis à saúde dos alunos. Diário Oficial do Estado de Roraima 2012; 1 ago.

20. Mato Grosso. Lei no 8.681, de 13 de julho de 2007 . Disciplina a alimentação oferecida nas unidades escolares, públicas e privadas, que atendam a educação infantil e básica do Estado de Mato Grosso. Diário Oficial do Estado de Mato Grosso 2007; 13 jul.

21. Mato Grosso do Sul. Lei no 4.320, de 26 de fevereiro de 2013. Proíbe a comercialização, confecção e distribuição de produtos que colaborem para acarretar riscos à saúde ou à segurança alimentar, dos consumidores, em cantinas e similares instalados em escolas públicas situadas no Estado de Mato Grosso do Sul e dá outras providências. Diário Oficial do Estado de Mato Grosso do Sul 2013; 27 fev.

22. Secretaria de Estado da Educação. Portaria no 038-R, de 06 de abril de 2010. Estabelece normas para o funcionamento das cantinas escolares dos estabelecimentos da rede estadual de ensino. Diário Oficial do Estado do Espírito Santo 2010; 7 abr.

23. Minas Gerais. Lei no 18.372 , de 04 de setembro de 2009. Acrescenta dispositivo à Lei no 15.072 , de 5 de abril de 2004, que dispõe sobre a promoção da educação alimentar e nutricional nas escolas públicas e privadas do sistema estadual de ensino. Diário Oficial do Estado de Minas Gerais 2009; 4 set.
24. Rio de Janeiro. Lei no 4.508, de 11 de janeiro de 2005. Proíbe a comercialização, aquisição, confecção e distribuição de produtos que colaborem para a obesidade infantil, em bares, cantinas e similares instalados em escolas públicas e privadas do Estado do Rio de Janeiro, na forma que menciona. Diário Oficial do Estado do Rio de Janeiro 2005; 11 fev.

25. Coordenadoria de Ensino da Região Metropolitana da Grande São Paulo. Portaria Conjunta COGSP/CEI/DSE, de 23-3-2005. Normas para funcionamento de cantinas escolares. Diário Oficial do Estado de São Paulo 2005; 24 mar.

26. Paraná. Lei no 14.855 , de 19 de outubro de 2005. Dispõe sobre padrões técnicos de qualidade nutricional, a serem seguidos pelas lanchonetes e similares, instaladas nas escolas de ensino fundamental e médio, particulares e da rede pública. Diário Oficial do Estado do Paraná 2005; 19 out.

27. Rio Grande do Sul. Lei no 13.027 , de 16 de agosto de 2008. Dispõe sobre a comercialização de lanches e de bebidas em escolas no âmbito do Estado do Rio Grande do Sul e dá outras providências. Diário Oficial do Estado do Rio Grande do Sul 2008; 18 ago.

28. Santa Catarina. Lei no 12.061 , de 18 de dezembro de 2001. Dispõe sobre critérios de concessão de serviços de lanches e bebidas nas unidades educacionais, localizadas no estado de Santa Catarina. Diário Oficial de Santa Catarina 2001; 20 dez.

29. Ministério da Saúde. Experiências estaduais e municipais de regulamentação da comercialização de alimentos em escolas no Brasil: identificação e sistematização do processo de construção e dispositivos legais adotados. Brasília: Ministério da Saúde; 2007.

30. Amazonas. Lei no 4.352, de 05 de julho de 2016. Dispõe sobre a proibição de comercialização, aquisição e distribuição de produtos que colaborem para a obesidade infantil, em cantinas e similares instalados em escolas públicas e privadas do Estado do Amazonas, na forma que menciona. Diário Oficial do Estado do Amazonas 2016; 5 jul.

31. Sergipe. Lei no 8.178-A, de 21 de dezembro de 2016. Proíbe a comercialização de produtos que colaborem para a obesidade infantil em cantinas e similares, instalados em escolas públicas e privadas situadas em todo o Estado de Sergipe. Diário Oficial do Estado de Sergipe 2017; 15 fev.

32. Paraíba. Lei no 10.431 , de 20 de janeiro de 2015. Proíbe cantinas e lanchonetes instaladas em escolas públicas e privadas de educação infantil, fundamental e média, de venderem bebidas com baixo teor nutricional, como os refrigerantes. Diário Oficial do Estado da Paraíba 2015; 21 jan.

33. Distrito Federal. Lei no 5.146, de 19 de agosto de 2013. Estabelece diretrizes para a promoção da alimentação saudável nas escolas da rede de ensino do Distrito Federal. Diário Oficial do Distrito Federal 2013; 21 ago. 
34. Distrito Federal. Decreto no 36.900 , de 23 de novembro de 2015. Regulamenta a Lei no 5.146, de 19 de agosto de 2013, que estabelece diretrizes para a promoção de alimentação adequada e saudável nas escolas da rede de ensino do Distrito Federal. Diário Oficial do Distrito Federal 2015; 24 nov.

35. Canella DS, Levy RB, Martins AP, Claro RM, Moubarac JC, Baraldi LG, et al. Ultra-processed food products and obesity in Brazilian households (2008-2009). PLoS One 2014; 9:e92752.

36. Day PI, Pearce JR, Pearson AL. A temporal analysis of the spatial clustering of food outlets around schools in Christchurch, New Zealand, 1966 to 2006. Public Health Nutr 2013; $18: 135-42$

37. Clark EM, Quigg R, Wong JE, Richards R, Black KE, Skidmore PML. Is the food environment surrounding schools associated with the diet quality of adolescents in Otago, New Zealand? Health Place 2014; 30:78-85.

38. Borradaile KE, Sherman S, Vander Veur SS, McCoy T, Sandoval B, Nachmani J, et al. Snacking in children: the role of urban corner stores. Pediatrics 2009; 124:1293-8.

39. Boyland EJ, Halford JC. Television advertising and branding. Effects on eating behaviour and food preferences in children. Appetite 2013; 62:236-41.

40. Costa SM, Horta PM, dos Santos LC. Food advertising and television exposure: influence on eating behavior and nutritional status of children and adolescents. Arch Latinoam Nutr 2012; 62:53-9.

41. Cervi MM, Agurs-Collins T, Dwyer LA, Thai CL, Moser RP, Nebeling LC. Susceptibility to food advertisements and sugar-sweetened beverage intake in non-Hispanic black and non-Hispanic white adolescents. J Community Health 2017; 42:748-56.

42. Organização Pan-Americana da Saúde. Recomendações da consulta de especialistas da Organização Pan-Americana da Saúde sobre a promoção e a publicidade de alimentos e bebidas não alcoólicas para crianças nas Américas. Washington DC: Organização Pan-Americana da Saúde; 2012.
43. Davison KK, Birch LL. Childhood overweight: a contextual model and recommendations for future research. Obes Rev 2001; 2:159-71.

44. World Health Organization. Global strategy on diet, physical activity and health. Fifty-seventh world health assembly. http://www.who.int/ gb/ebwha/pdf_files/WHA57/A57_R17-en.pdf (accessed on 21/Dez/2017).

45. Ministério da Saúde. Portaria no 596, de 8 de abril de 2004. Diário Oficial da União 2004; 12 abr.

46. Departamento de Análise de Situação de Saúde, Secretaria de Vigilância em Saúde, Ministério da Saúde. Plano de ações estratégicas para o enfrentamento das doenças crônicas não transmissíveis (DCNT) no Brasil 2011-2022. Brasília: Ministério da Saúde; 2011.

47. Câmara Interministerial de Segurança Alimentar e Nutricional, Ministério do Desenvolvimento Social e de Combate à Fome. Estratégia Intersetorial de Prevenção e Controle da Obesidade: promovendo modos de vida e alimentação adequada e saudável para a população brasileira. Brasília: Câmara Interministerial de Segurança Alimentar e Nutricional, Ministério do Desenvolvimento Social e de Combate à Fome; 2014.

48. Corrêa EN, Schmitz BAS, Vasconcelos FAG. Aspects of the built environment associated with obesity in children and adolescents: a narrative review. Rev Nutr 2015; 28:327-40.

49. Oreskovic NM, Winickoff JP, Kuhlthau KA, Romm D, Perrin JM. Obesity and the built environment among Massachusetts children. Clin Pediatr 2009; 48:904-12. 


\section{Resumo}

O estudo teve como objetivo caracterizar o ambiente alimentar das escolas públicas e privadas no Brasil. Este foi um estudo transversal nacional de base escolar com 1.247 escolas (81,09\% públicas e 18,91\% privadas) em 124 municípios brasileiros. Os dados foram obtidos do Questionário sobre Aspectos do Ambiente Escolar utilizado no Estudo de Riscos Cardiovasculares em Adolescentes (ERICA) em 2013 e 2014. Os dados foram analisados em 2017. O teste do qui-quadrado foi usado para comparar as proporções. Proporcionalmente mais escolas públicas ofereciam refeições escolares (98,15\%), em comparação com as escolas privadas $(8,07 \%)(p<0,001)$. A venda de alimentos e bebidas no ambiente escolar interno era mais prevalente nas escolas privadas $(97,75 \%$ vs. 45,06\%, $p<0,001$ ). Além disso, a propaganda e venda de alimentos processados e ultra-processados (refrigerantes, biscoitos, salgadinhos, sanduiches e pizza) também eram mais comuns nas escolas privadas, assim como, a presença de máquinas de autoatendimento com venda de produtos industrializados $(18,02 \%$ vs. $4 \%)(p<0,001)$. Os vendedores ambulantes no portão ou nos arredores da escola foram identificados em 41,32\% das escolas públicas e $47,75 \%$ das escolas privadas ( $p$ $>0,05)$. Os achados revelam a predominância de ambientes obesogênicos, especialmente nas escolas privadas, e podem contribuir para a elaboração de politicas públicas brasileiras para promover um ambiente alimentar saudável nas escolas.

Alimentação; Adolescente; Instituições Acadêmicas

\section{Resumen}

El objetivo de este estudio fue caracterizar el ambiente alimentario de las escuelas públicas y privadas en Brasil. Se trata de un estudio transversal nacional con base escolar, en 1.247 escuelas (81,09\% públicas y 18,91\% privadas), de 124 municipios brasileños. Los datos se obtuvieron del Cuestionario sobre Aspectos del Ambiente Escolar, utilizado en el Estudio de Riesgos Cardiovasculares en Adolescentes (ERICA) en 2013 y 2014. Los datos fueron analizados en 2017. El test de chi-cuadrado se usó para comparar las proporciones. Proporcionalmente, más escuelas públicas ofrecían comidas escolares (98,15\%), en comparación con las escuelas privadas $(8,07 \%)$ ( $p<0,001)$. La venta de alimentos y bebidas en el ambiente interno escolar era más prevalente en las escuelas privadas (97,75\% vs. 45,06\%, $p<$ 0,001 . Además, la propaganda y venta de alimentos procesados y ultraprocesados (refrescos, galletas, aperitivos, sándwiches y pizza) también eran más comunes en las escuelas privadas, así como la presencia de máquinas de autoservicio con venta de productos industrializados (18,02\% vs. 4\%) ( $p<$ $0,001)$. Los vendedores ambulantes a la puerta de la escuela o en los alrededores de la escuela fueron identificados en un 41,32\% de las escuelas públicas y 47,75\% de las escuelas privadas ( $p>0,05)$. Los hallazgos revelan la predominancia de ambientes obesogénicos, especialmente en las escuelas privadas, y pueden contribuir a la elaboración de politicas públicas brasileñas para promover un ambiente alimentario saludable en las escuelas.

Alimentación; Adolescente; Instituciones

Académicas
Submitted on $25 / \mathrm{Jan} / 2018$

Final version resubmitted on 15/May/2018

Approved on 15/Aug/2018 